\title{
Regeneration of Intergeneric Somatic Hybrids by Electrical Fusion between Citrus and Its Wild Relatives: Mexican Lime (Citrus

\author{
aurantifolia) and Java Feroniella (Feroniella lucida) \\ or Tabog (Swinglea glutinosa)
}

\author{
Rika Takayanagi*, Tetsushi Hidaka** and Mitsuo Omura \\ Okitsu Branch, Fruit Tree Research Station, Okitsu, Shimizu, Shizuoka 424-02
}

\begin{abstract}
Summary
Electrical fusion of protoplasts was used to produce somatic hybrids between Mexican lime (Citrus aurantifolia Swingle) and Java feroniella (Feroniella lucida (Sceff.) Swingle) or tabog (Swinglea glutinosa (Blanco) Merr.). The fusion efficiency (rates of formation of binuclear heterokaryons) were around $15 \%$. The fusion products were cultured and embryoids were differentiated from them. The embryoids were transferred to a medium for plantlet formation and grew into plantlets. The rDNA analysis confirmed that the differentiated plantlets from these two combinations have genomes from both parents. The results confirmed that our electrical fusion system is an effective method for producing somatic hybrids of citrus and its sexually incompatible wild relatives.
\end{abstract}

\section{Introduction}

Progress in developing higher plants resistant to pests and pathogens is often restrained by the fact that wild species which carry desirable traits cannot be cross-bred with cultivated species. To bypass sexual incompatibility, the production of somatic hybrids by protoplast fusion and the subsequent regeneration of hybrid plants is a newly elaborated alternative method to that of sexual crossing in higher plants.

Since the first somatic hybrid plants of citrus between Citrus sinensis $\backslash$ nd Poncirus trifoliata were regenerated by Ohgawara et al. (10), a number of additional somatic hybrids among Citrus and related genera have been reported $(1,2,3,7,8,11)$. Vardi et al. (16) has reported the production of cybrid citrus plants. However, most of these somatic hybrids were produced from sexually compatible species and only two sexually incompatible species; that being the regeneration of somatic

Received for publication 12 August 1991.

* Present address: Agr. Res. Inst. Kanagawa Prefect., 496, Teradanawa, Hiratsuka, Kanagawa 259-12.

** Author to whom correspondence should be addressed. hybrid plants from Citrus sinensis and Severinia disticha (2), and from Citrus sinensis and Citropsis gilletiana (3). Severinia and Citropsis belong to the subtribe Citrinae in which Citrus belongs also. These somatic hybrids were obtained by polyethylene glycol (PEG) mediated fusion. We have recently reported an efficient electrical fusion system which was used to produce somatic hybrid plants of Citrus (5). In this paper, we describe the regeneration of intergeneric somatic hybrid plants produced from cell fusion of sexually incompatible species; Mexican lime (Citrus aurantifolia Swingle), which belongs to the subtribe Citrinae, and Java feroniella (Feroniella lucida (Sceff.) Swingle) or tabog (Swinglea glutinosa (Blanco) Merr.), which 2 species belong to the different subtribe $\mathrm{Bal}$ samocitrinae. This is the first report of the somatic hybrid from the fusion between the subtribes Citrinae and Balsamocitrinae.

\section{Materials and Methods}

\section{Plant materials}

Protoplasts were isolated from callus and leaves. Embryo derived callus of Mexican lime was induced as described earlier (4). Excised embryos from young immature seeds were plated on callus 
induction medium. The medium was based on Murashige and Skoog (9) (MS) containing 0.2 M sucrose and $50 \mu \mathrm{M}$ kinetin and solidified with $0.2 \%$ Gelrite (Kelco, Merck \& Co. Inc., USA). Induced callus were subcultured on the same medium and maintained with a 16-hr photoperiod (warm-white fluorescent lamps, $25 \sim 35 \mu \mathrm{E} \cdot \mathrm{m}^{-2} \cdot \mathrm{sec}^{-1}$ ) at $25^{\circ} \pm$ $1^{\circ} \mathrm{C}$. These callus lines have maintained an embryogenic potential after 8 to 10 years of subculture.

Seeds of Java feroniella and tabog were germinated in Petri dishes and planted in a potting mixture. They were grown in a greenhouse at $25^{\circ} \sim 35^{\circ} \mathrm{C}$ without supplemental lighting. Leaf protoplasts of these species were isolated from leaves of 5- to 6-year-old plants as described previously (5).

\section{Protoplast isolation}

Prior to isolation of protoplasts, the callus cultures were transferred from the solidified subculture medium to a liquid MS medium containing same components and shaken on an orbital shaker $(140 \mathrm{rpm})$ with a $16-\mathrm{hr}$ photoperiod (warm-white fluorescent lamps, $25 \sim 35 \mu \mathrm{E} \cdot \mathrm{m}^{-2} \cdot \mathrm{sec}^{-1}$ ) at $25^{\circ} \pm$ $1^{\circ} \mathrm{C}$. They were subcultured at least 3 times every 2 weeks. The cultures were then transferred to a liquid MS medium containing $0.1 \mathrm{M}$ galactose and $0.1 \mathrm{M}$ sorbitol and maintained for one week or more. For the suspension culture-derived protoplasts, about $1 \mathrm{~g}$ of callus after 1 week of transfer were collected and macerated by the method of Vardi and Spiegel-Roy (15) with slight modification. The maceration medium ( $\mathrm{pH} 5.6$ ) contained half strength MS medium with $0.3 \%$ Macerozyme R-10 (Yakult Pharmaceutical Co. Ltd., Nishinomiya, Japan), $0.3 \%$ Cellulase Onozuka R-10 (Yakult Pharmaceutical Co. Ltd. Nishinomiya, Japan, 0.35 M mannitol and 0.35 M sorbitol. Digestion was carried out at $25^{\circ} \pm 1^{\circ} \mathrm{C}$ for $16 \mathrm{hr}$.

Five to six fully expanded leaves of Java feroniella and one to two leaves of tabog were collected and surface sterilized with $70 \%$ ethanol. The leaves were then immersed in a solution containing $0.5 \%$ sodium hypochlorite for $10 \mathrm{~min}$ and washed three times with sterile distilled water. The leaves were cut into small pieces (about $2 \mathrm{~mm}$ $\times 2 \mathrm{~mm}$ ) by a sterilized razor blade and transferred into a $100 \mathrm{ml}$ Erlenmeyer flask containing half strength MS liquid medium supplemented with $0.7 \mathrm{M}$ mannitol. For the pretreatment, they were shaken by an orbital shaker $(140 \mathrm{rpm})$ for about $1 \mathrm{hr}$ at $25^{\circ} \pm 1^{\circ} \mathrm{C}$. After removal of the preincubation medium, the leaf pieces were incubated with $40 \mathrm{ml}$ enzyme solution ( $\mathrm{pH} \mathrm{5.6)} \mathrm{con-}$ taining $1 / 2 \mathrm{MS}$ medium with $0.3 \%$ Macerozyme R-10, 3.0\% Cellulase Onozuka R-10, $1 \mathrm{mM} \mathrm{N-}$ morpholinoethane sulfonic acid (MES), $0.35 \mathrm{M}$ mannitol and $0.35 \mathrm{M}$ sorbitol. Digestion was carried out at $25^{\circ} \pm 1^{\circ} \mathrm{C}$ for $16 \mathrm{hr}$.

Protoplasts were filtered through a layer of Miracloth (Calbiochem, USA), washed and centrifuged $(100 \times \mathrm{g}) 3$ times with fusion solution containing $0.35 \mathrm{M}$ mannitol, $0.35 \mathrm{M}$ sorbitol and $0.25 \mathrm{mM}$ calcium chloride.

\section{Protoplast fusion}

The electric fields necessary to induce protoplast fusion were generated by a power supply (RSG-1000, Hoei Sci. Co. Ltd., Tokyo, Japan). Electrical fusion was carried out using an electrode (FTC-33D5, the Shimadzu Co. Ltd., Kyoto, Japan) with $4 \mathrm{ml}$ solution in a plastic Petri dish $(60 \mathrm{~mm}$ diameter, $15 \mathrm{~mm}$ high).

The electrical parameters used in this experiment to induce protoplast fusion were as follows: AC field, $1 \mathrm{MHz}, 125 \mathrm{~V} \cdot \mathrm{cm}^{-1}, 60 \mathrm{sec}$; DC field, $1,250 \mathrm{~V} \cdot \mathrm{cm}^{-1}$ square-wave $50 \mu \mathrm{sec}$ in duration, 5 times at $1 \mathrm{sec}$ intervals.

For fusion, a protoplast mixture was prepared which contained $2 \sim 6 \times 10^{5}$ callus protoplasts and $5 \sim 50 \times 10^{5}$ mesophyll protoplasts resuspended in the fusion solution previously described. Four $\mathrm{ml}$ of this mixture was transferred to a plastic Petri dish (60 mm diameter, $15 \mathrm{~mm}$ high) and fusion was induced. Mixtures were allows to remain still for at least $10 \mathrm{~min}$ after fusion, then transferred to $10 \mathrm{ml}$ tubes and pelleted by centrifugation at $100 \times \mathrm{g}$ for $7 \mathrm{~min}$. The supernatant was discarded and the fusion products were resuspended at a density of $2 \times 10^{5}$ cells in an MS medium with $0.6 \mathrm{M}$ sucrse according to the method of Ohgawara et al. (10). After transfer of $2 \mathrm{ml}$ mixture into a plastic Petri dish, an equal volume of a liquid MS medium with $1.6 \%$ agar, and $0.6 \%$ sucrose was added, mixed and allowed to solidify. The cultures were incubated with a photoperiod of $16 \mathrm{hr}$ (warmwhite fluorescent lamps, $2 \sim 4 \mu \mathrm{E} \cdot \mathrm{m}^{-2} \cdot \mathrm{sec}^{-1}$ ) for 3 weeks and then transferred to a higher light intensity of $20 \sim 30 \mu \mathrm{E} \cdot \mathrm{m}^{-2} \cdot \mathrm{sec}^{-1}$. Embryoids which de- 
veloped were transplanted onto an MS medium (solidified with $0.2 \%$ Gelrite) containing $0.1 \mathrm{M}$ galactose, $0.1 \mathrm{M}$ sorbitol and $1 \mu \mathrm{M}$ gibberellic acid in $20 \times 100 \mathrm{~mm}$ culture tubes.

\section{DNA analysis}

For DNA analysis, tissues of differentiated plantlets in culture tubes and parental callus and leaves were collected and freeze-dried. Total DNA was extracted from the samples according to the sodium dodecylsulfate (SDS) micro-preparation method of Honda and Hirai (6) with slight modification.

Thirty $\mathrm{mg}$ of freeze-dried tissue was homogenized with a mortar and pestle and was transferred to a $1.5 \mathrm{ml}$ polypropylene microtube. Five hundred $\mu \mathrm{l}$ of extraction buffer $(100 \mathrm{mM}$ 2-amino-2-hydroxymethyl-1, 3-propanediol - hydrochloric acid (Tris-HCl) pH 8.0, $50 \mathrm{mM}$ ethylenediaminetetraacetic acid disodium salt (EDTA) $\mathrm{pH} 8.0,500 \mathrm{mM}$ sodium chloride $(\mathrm{NaCl}), 0.2 \%$ 2-mercaptoethanol) was then added. Small samples were ground directly with $500 \mu$ l of extraction buffer and then transferred to a $1.5 \mathrm{ml}$ microtube. The homogenate was mixed with $100 \mu \mathrm{l}$ of $10 \%$ SDS and incubated at $65^{\circ} \mathrm{C}$ for $20 \mathrm{~min}$. Two hundred $\mu \mathrm{l}$ of $5 \mathrm{M}$ potassium acetate was added and the mixture was incubated on ice for $20 \mathrm{~min}$. After centrifugation at $15,000 \mathrm{rpm}$ for $10 \mathrm{~min}$, the supernatant was transferred to a new $1.5 \mathrm{ml}$ microtube, mixed with $400 \mu \mathrm{l}$ of isopropanol and placed at $-70^{\circ} \mathrm{C}$ for $30 \mathrm{~min}$. After the mixture was centrifuged at $15,000 \mathrm{rpm}$ for $20 \mathrm{~min}$, the supernatant discarded and the pellet briefly dried. The pellet was dissolved in $100 \mu \mathrm{l}$ of $50 \mathrm{mM}$ Tris$\mathrm{HCl} \mathrm{pH} 8.0,10 \mathrm{mM}$ EDTA $\mathrm{pH} 8.0$, and centrifuged at $15,000 \mathrm{rpm}$ for $10 \mathrm{~min}$. The supernatant was transferred to a new $1.5 \mathrm{ml}$ microtube and mixed with $10 \mu \mathrm{l}$ of $3 \mathrm{M}$ sodium acetate $\mathrm{pH} 5.2$ and $100 \mu \mathrm{l}$ isopropanol. After incubation at $-70^{\circ} \mathrm{C}$ for $15 \mathrm{~min}$, the mixture was centrifuged at $15,000 \mathrm{rpm}$ for $20 \mathrm{~min}$. The pellet was rinsed with $-20^{\circ} \mathrm{C} 70 \%$ ethanol and dissolved in $50 \mu 1 \mathrm{TE}$ buffer (10 mM Tris-HCI pH 8.0, 1 mM EDTA pH 8.0). The mixture was centrifuged at $15,000 \mathrm{rpm}$ for $5 \mathrm{~min}$ and supernatant was transferred to a new $1.5 \mathrm{ml}$ microtube.

After quantifying the amount of DNA, aliquots of $5 \mu \mathrm{g}$ from each parent and differentiated plantlets were digested separately with various restriction endonucleases ( $A f a \mathrm{I}, B a m \mathrm{HI}$ and $X h o \mathrm{I}$ ). After electrophoresis in $0.8 \%$ agarose gels, the digested DNA was treated with ultraviolet-light $(300 \mathrm{~nm})$ for $5 \mathrm{~min}$ and transferred to nylon membrane (Hybond$\mathrm{N}+$, Amersham, UK) with $0.4 \mathrm{M} \mathrm{NaOH}$ solution. The blots were probed with $7.7 \mathrm{kbp}$ EcoRI fragments from rice-rDNA (14) labeled with peroxidase complexes, for visualization by the non-radioisotopic gene detection system, ECL (Amersham, UK).

\section{Results and Discussion}

Following fusion and 5 to 10 weeks of culture, small callus colonies became visible in Petri dishes. Several green embryoids developed after 12 to 14 weeks of culture. However, the number of those embryoids were around 50 per Petri dish, which is fewer than that of the combinations between Citrus reported (5). Embryoids were transplanted to a new medium in culture tubes for further development. Some of them formed shoots and roots, however, many shoots were deformed (Figs. 1 and 2).

DNA analysis (Figs. 3 and 4) confirmed the hybridity of the regenerated plantlets of both combinations of Mexican lime $\times$ Java feroniella or tabog. Among the restriction enzymes tested, Afal (Fig. 3a), BamHI (Fig. 3b) and XhoI (Fig. 3c) released specific fragments for Mexican lime, Java feroniella and their somatic hybrids, and BamHI (Fig. 4) released specific fragments for Mexican lime, tabog and their somatic hybrids. In the Mexican lime $\times$ Java feroniella somatic hybrid, 2 specific fragments for each species were present between $6.5 \sim 2.3 \mathrm{kbp}$ by $A f a \mathrm{I}$. Two specific fragments for Mexican lime were present under $2.3 \mathrm{kbp}$ by $\mathrm{BamHI}$ and also 2 specific fragments for Java feroniella were present between $4.4 \sim 2.3 \mathrm{kbp}$ by XhoI. In the Mexican lime $\times$ tabog somatic hybrid, 3 fragments specific for each species were present under $2.3 \mathrm{kbp}$ by $B a m H I$.

We have previously described the electrical fusion system for Citrus (5). Sexually incompatible somatic hybrids were reported in two combinations between Citrus and its wild relatives so far: $C$. sinensis and Severinia disticha (2), and $C$. sinensis and Citropsis gilletiana (3). According to Swingle's classification (12), these three species belong to the subtribe Citrinae of the orange subfamily Aurantioideae. This subtribe is divided into 3 subtribal groups. Citrus belongs to the group of "true citrus 

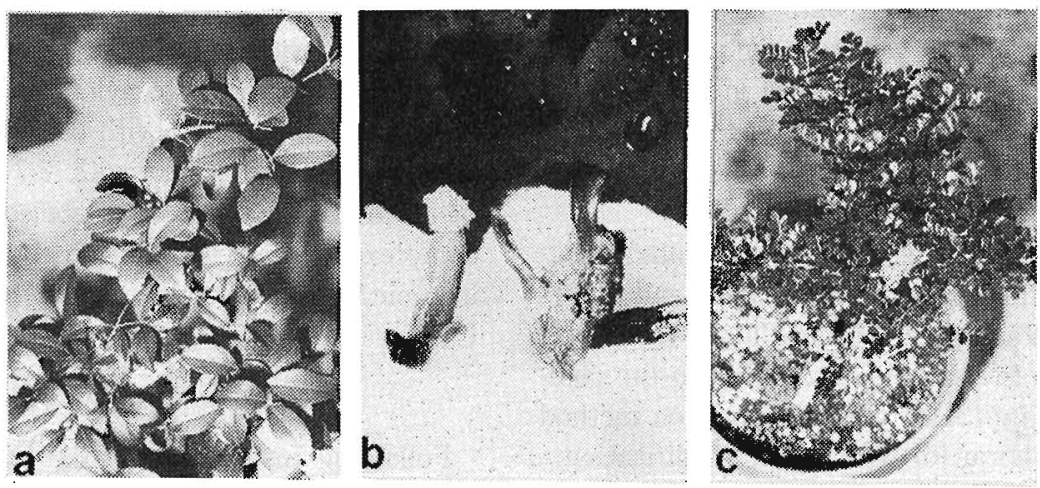

Fig. 1. Somatic hybrids resulting from the fusion of protoplasts from Mexican lime (Citrus aurantifolia) and Java feroniella (Feroniella lucida).

a: Mexican lime. b: Somatic hybrid from Mexican lime and Java feroniella. c: Java feroniella.

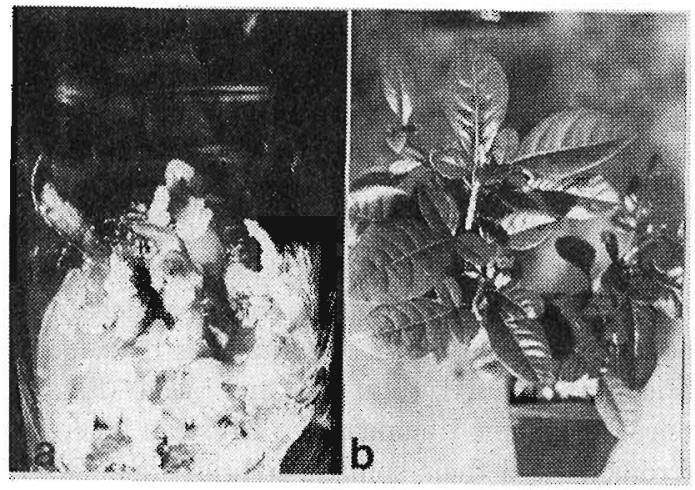

Fig. 2. Somatic hybrids resulting from the fusion of protoplasts from Mexican lime (Citrus aurantifolia) and tabog (Swinglea glutinosa). a: Somatic hybrid from Mexican lime and tabog. b: Tabog.

fruit trees". While Citropsis belongs to the group of "near-citrus fruit trees" and Severinia belongs to the group of "primitive citrus fruit trees". Citropsis, Severinia and several other relatives in Citrinae, which are potentially important for Citrus genetic improvement, are graft-compatible with Citrus, but sexually incompatible (13). Java feroniella and tabog used in our experiment belong to a different subtribe Balsamocitrinae which divided into 3 subtribal groups. Java feroniella belongs to "woodapple group" and tabog is a member of "tabog group". Citrus is sexually incompatible with them, however, can be grafted on tabog and in some cases on Java feroniella (13). Tabog grows well in sandy loam and porous limestone soils and may be a source of tolerance to these conditions, and Java

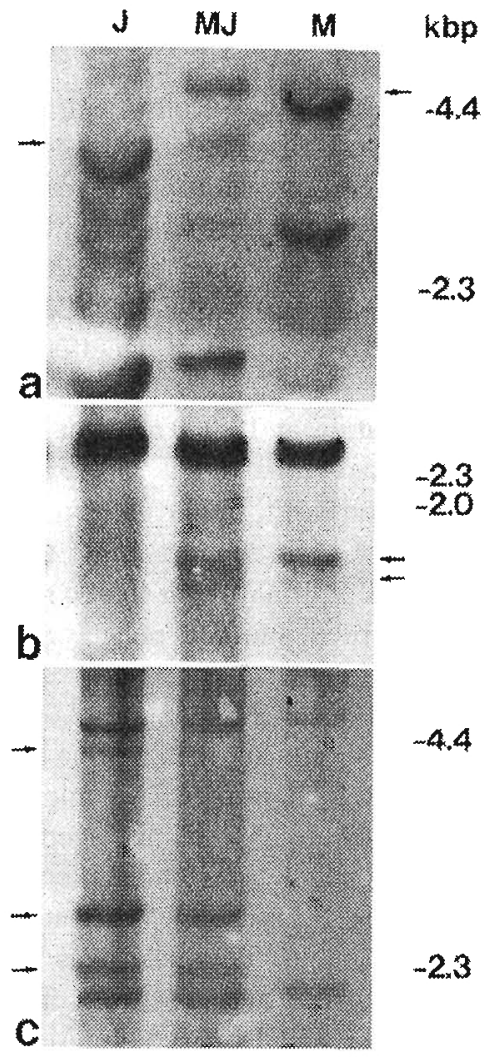

Fig. 3. DNA blot hybridized to $7.7 \mathrm{kbp} E c o$ RI fragments from rice-rDNA labeled with peroxidase complexes in a combination between Mexican lime and Java feroniella. M: Mexican lime, J: Java feroniella, MJ: somatic hybrid between Mexican lime and Java feroniella. Arrows indicate unique bands present in somatic hybrid and the parents. a. Blot with Afal-digested DNA. b. Blot with BamHI-digested DNA. c. Blot with XhoI-digested DNA. 


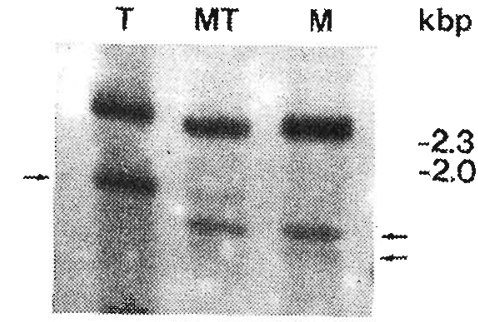

Fig. 4. Blot with BamHI-digested DNA extracted from Mexican lime, tabog and a somatic hybrid hybridized to $7.7 \mathrm{kbp}$ EcoRI fragments from rice-rDNA labeled with peroxidase complexes. M: Mexican lime, T: Tabog, MT: Somatic hybrid between Mexican lime and tabog. Arrows indicate unique bands present in somatic hybrid and the parents.

feroniella will be a source of dwarfing rootstocks (13). However, they cannot be used directly because of severe dwarfism and cold sensitivity. Remote relatives of Citrus may have more potential as sources of germplasm of rootstocks for genetic improvement of Citrus.

The electrical fusion system described here is an efficient system for producing somatic hybrids between Citrus and its remote relatives as well as for producing somatic hybrids among Citrus spp. as described previously (5). Future work will attempt to create somatic hybrids between Citrus and other species of Aurantioideae, orange subfamily.

\section{Acknowledgment}

We express sincere thanks to Dr. M. A. Berhow (STA fellow) for his kind revision of manuscript.

\section{Literature Cited}

1. Grosser, J.W., F. G. Gmitter and J.L. Chandier. 1988. Intergeneric somatic hybrid plants of Citrus sinensis $\mathrm{cv}$. Hamlin and Poncirus trifoliata cv. Flying Dragon. Plant Cell Rep. 7:5-8.

2. Grosser, J.W., F. G. Gmitter and J.L. Chandler. 1988. Intergeneric somatic hybrid plants from sexually incompatible woody species: Citrus sinensis and Severinia disticha. Theor. Appl. Genet. $75: 397-401$.

3. Grosser, J.W., F.G. Gmitter, N. Tusa and J.L. Chandler. 1990. Somatic hybrid plants from sexually incompatible woody species: Citrus reticulata and Citropsis gilletiana. Plant Cell Rep. $8: 656-659$.

4. Hidaka, T. and M. Omura. 1989. Control of embryogenesis in Citrus cell culture: Regeneration from protoplasts and attempts to callus bank. Fruit Tree Res. Stn. B 16:1-17.
5. Hidaka, T. and M. Omura. 1992. Regeneration of somatic hybrid plants obtained by electrical fusion between satsuma mandarin (Citrus unshiu) and rough lemon (C. jambhiri) or yuzu (C. junos). Japan. J. Breed. 42. (In Press).

6. Honda, H. and A. Hirai. 1990. A simple and efficient method for identification of hybrids using nonradioactive rDNA as probe. Japan. J. Breed. $40: 339-348$.

7. Kobayashi, S., T. Ohgawara, E. Ohgawara, I. Oiyama and S. Ishii. 1988. A somatic hybrid plant obtained by protoplast fusion between navel orange (Citrus sinensis) and satsuma mandarin (C. unshiu). Plant Cell Tissue Organ Culture $14: 63-69$.

8. Kobayashi, S., T. Ohgawara, E. Ohgawara, I. Oiyama and S. Ishii. 1988. Somatic hybridization between Navel orange and 'Murcott' Tangor. p.23-28. In : R. Goren and K. Mendel (eds.). Proc. 6th Int. Citrus Congr. Tel Aviv.

9. Murashige, T. and F. Skoog. 1962. A revised medium for rapid growth and bioassays with tobacco tissue culture. Physiol. Plant. 15 : 473-497.

10. Ohgawara, T., S. Kobayashi, E. Ohgawara, H. Uchimiya and S. Ishii. 1985. Somatic hybrid plants obtained by protoplast fusion between Citrus sinensis and Poncirus trifoliata. Theor. Appl. Genet. $71: 1-4$.

11. Ohgawara, T., S. Kobayashi, S. Ishii, K. Yoshinaga and I. Oiyama. 1989. Somatic hybridization in Citrus: Navel orange (C. sinensis Osb.) and grapefruit (C. paradisi Macf.). Theor, Appl. Genet. $78: 609-612$.

12. Swingle, W. T. 1943. The botany of Citrus and its relatives of the orange subfamily. p. 129-474. In: H.J. Webber and L.D. Batchelor (eds.). The citrus industry. Vol. I. Univ. Calif. Press, Berkeley and Los Angeles., Calif.," U.S.A.

13. Swingle, W.T. and P.C. Reece. 1967. The botany of Citrus and its wild relatives. p.190-430. In: W. Reuther, H.J. Webber and L.D. Batchelor (eds.). The citrus industry Vol. I. Univ. Calif. Press, Berkeley, Calif., U.S.A.

14. Takaiwa, F., K. Oono and M. Sugiura. 1984. The complete nucleotide sequence of a rice $17 \mathrm{~s}$ rRNA gene. Nucleic Acids Res. $12: 5441-5448$.

15. Vardi, A. and P. Spiegel-Roy. 1982. Plant regeneration from Citrus protoplasts: Variability in methodological requirements among cultivars and species. Theor. Appl. Genet. 62:171-176.

16. Vardi, A., P. Arzee-Gonen, A. Frydman-Shani, S. Bleichman and E. Galun. 1989. Protoplast-fusionmediated transfer of organelles from Microcitrus into Citrus and regeneration of novel alloplasmic trees. Theor. Appl. Genet. $78: 741-747$. 
電気融合法によるカンキツとその近縁野生種との体細胞雑種の作出：

メキシカンライム (Citrus aurantifolia) と，ジャワフェロニエラ (Feroniella lucida) およびタボッグ (Swinglea glutinosa) との細胞融合

高柳りが ・ 日高哲志・大村三男

\title{
果樹試験場興津支場 $424-02$ 静岡淙清水市
}

\begin{abstract}
摘 要
カンキツ類縁種の有用遗伝子を栽培種へ導入するた 融合したプロトプラストを培殶したところ，緑色の め，カンキツとその近縁野生種 2 種との電気細胞融合 を試み，それぞれ融合個体を得た。

一方のカンキツのプロトプラストはメキシカンライ 胚㥞体が得られた。それらを植物体形成培地に移し， さらなる生長を图ったが，荎葉を形成するものは少な く，形成された菜葉は奇形を呈するものも多かった。 ムの胚起源カルスから得, 一方のプロトプラストには 形成された植物体の一部扔よび用いたカルス，葉か ジャワフェロニエラ (Feroniella lucida) および夕ボッ グ(Swinglea glutinosa)の葉肉から得たものを用いた。 奉験を通じての融合効率（へテロカリオンの形成率） は15\%前後であった。 ら DNAを抽出し，イネrDNAをプローブとして genomic southern hybridization を行ったところ, 得 られた個体は体細胞雑種であることが明らかになった。
\end{abstract}

